УДК 354
А. В. Полянин
ФГБОУ ВО «Российская академия народного хозяйства и государственной службы при Президенте РФ» Среднерусский институт управления-филиал, Орел, e-mail: polyanin.andrei@yandex.ru

\title{
С. А. Долгова
}

ФГБОУ ВО «Российская академия народного хозяйства и государственной службы при Президенте РФ» Среднерусский институт управления-филиал, Орел, e-mail: s_a_dolgova@mail.ru

\section{Ю. Б. Голикова}

ФГБОУ ВО «Гжельский государственный университет», Москва, e-mail: golikova-yb@bk.ru

\section{МЕХАНИЗМЫ ГОСУДАРСТВЕННОГО АНТИКРИЗИСНОГО УПРАВЛЕНИЯ ТЕРРИТОРИЯМИ}

Ключевые слова: экономический кризис, антикризисные меры, механизмы государственного антикризисного управления, национальные проекты.

Рыночная экономика породила ряд проблем, важнейшей из которых является проблема антикризисного управления, получившая распространение в годы мирового финансового кризиса 2000-х годов. Кризисы независимо от того, в какой бы сфере общественной жизни не происходили, становятся все более распространенными во всем мире, управлять которыми не всегда просто, что особенно актуально в современных реалиях экономического развития. Сегодня в условиях изменения общественных отношений, не только среди внутреннего окружения, но и на международном уровне, государственное антикризисное управление является необходимым аспектом благополучия и стабильности развития. Закономерно возникает вопрос о месте и роли государства в обеспечении экономической жизнедеятельности общества в условиях кризиса, формах и методах воздействия для нивелирования его разрушительных последствий, в связи с чем появляется необходимость более глубокого осмысления изменения роли государства в урегулировании происходящих процессов на основе анализа предпринятых мер, что будет способствовать формированию, адекватной их состоянию, оценки, и на ее основе разработки мероприятий по решению прорывных задач развития России.

\section{A. V. Polyanin}

«Russian presidential Academy of national economy and public administration»

Central Russian Institute of management-branch, Orel, e-mail: polyanin.andrei@yandex.ru

\section{S. A. Dolgova}

«Russian presidential Academy of national economy and public administration»

Central Russian Institute of management-branch, Orel, e-mail: s_a_dolgova@mail.ru

\section{Yu. B. Golikova}

Gzhel State University, Moscow, e-mail: golikova-yb@bk.ru

\section{MECHANISMS OF STATE ANTI-CRISIS MANAGEMENT OF TERRITORIES}

Keywords: economic crisis, anti-crisis measures, mechanisms of state anti-crisis management, national projects.

The market economy has created a number of problems, the most important of which is the problem of crisis management, which became widespread during the world financial crisis of the 2000s. Crises, regardless of what sphere of public life they occur in, are becoming more and more common all over the world, which is not always easy to manage, which is especially important in the current realities of economic development. Today, in the context of changing social relations, not only among the domestic environment, but also at the international level, state anti-crisis management is a necessary aspect of well-being and stability of development. The question naturally arises about the place and role of the state in ensuring the economic functioning of companies in crisis conditions, forms and methods of influence in order to mitigate its devastating impact, therefore there is a need for a deeper understanding of the changing role of the state in the regulation of the processes based on the analysis of the undertaken measures that will contribute to the formation adequate to their status, assessments, and based on it develop measures to deal with disruptive challenges to the development of Russia. 


\begin{abstract}
Введение
Глобальный экономический кризис бросил вызов правительствам всех стран, и несмотря на то, что для его преодоления были использованы огромные финансовые ресурсы, до сих пор ни одной стране не удалось найти выход. Поиск эффективных решений, которые могли бы минимизировать и преодолеть последствия кризиса тесно связаны с выработкой новых идей по антикризисным мерам. Сегодня, когда десятки антикризисных мер вступили в свою практическую стадию, пришло время, с одной стороны, принять новые меры, запустить более сложные механизмы их мониторинга и, с другой стороны, включить процедуры специальной предварительной оценки при создании новых проектов по антикризисным мерам. Причиной принятия такого шага является осознание того, что ресурсы и резервы, имеющиеся для поддержки экономики ограничены, особенно в ситуации, когда наиболее быстрый выход из кризиса становится все менее и менее вероятным. Изменения будут необходимым предварительным условием для сдвига в экономической политики, вдали от «оружия театра военных действий», которое, должно облегчить последствия кризиса и восстановление ущерба, нанесенного наиболее уязвимым секторам экономики, более короткий горизонт экономической политики неизбежен в острой фазе кризиса, а постоянный мониторинг предпринятых мер и наиболее правильная предварительная оценка новых будут способствовать удлинению горизонта и позволят объединить текущую политику с заявленными стратегическими приоритетами что и было сделано Правительством.
\end{abstract}

\section{Цель исследования}

Анализ механизмов государственного антикризисного управления в целях определения проблемных аспектов и разработки предложений по их развитию.

\section{Материал и методы исследования}

Основными источниками для анализа реализации механизмов государственного антикризисного управления послужила открытая информация Правительства России, Национального рейтингового Агентства, данные Росстата и РБК, исследование проводилось на основе общенаучных методов познания.

\section{Результаты исследования}

В целях реализации государственной политики антикризисного управления для обеспечения в долгосрочной перспективе устойчивого повышения благосостояния российских граждан, национальной безопасности, динамичного развития экономики и укрепления позиций России в мировом сообществе в 2008 году была принята «Концепция долгосрочного социально-экономического развития Российской Федерации» на период до 2020 года «Стратегии-2020».

Стратегии выстраивает систему приоритетных направлений политики государства в экономической сфере, чтобы вывести её на новый путь развития по конкретным показателям роста товаров и услуг, т.е. повышение удельного веса экспорта новаторской продукции, роста её конкурентоспособности [9].

Главенствующая цель - достижение уровня экономического и социального развития, соответствующего статусу России как ведущей мировой державы XXI века, занимающей передовые позиции в глобальной экономической конкуренции и надежно обеспечивающей национальную безопасность и реализацию конституционных прав граждан, достижение которой будет способствовать формированию качественно нового образа России [5].

Формальный срок действия Концепции заканчивается в 2020 году, по ряду целевых индикаторов срок документа фактически продлен - они стали национальными целями, закрепленными майским указом Президента в 2018 году [1].

Согласно Концепции, за период 2015-2020 гг. Россия должна войти в пятерку стран-лидеров по объему ВВП, фактически по итогам 2018 года Россия находится на шестом месте - 3,1\% мирового ВВП, а первая пятерка представлена Китаем - 18,7\%, США - 15,2\%, Индией $-7,7 \%$, Японией $-4,1 \%$ и Германией $-3,2 \%$ (рис. 1).

Согласно Концепции, к 2020 году по сравнению с 2012 годом реальный ВВП должен был вырасти на 64-66\%, однако за период 2013-2019 годы рост составил всего лишь 5,8\% (с учетом последних прогнозов властей по текущему году) (рис. 2) [1]. 


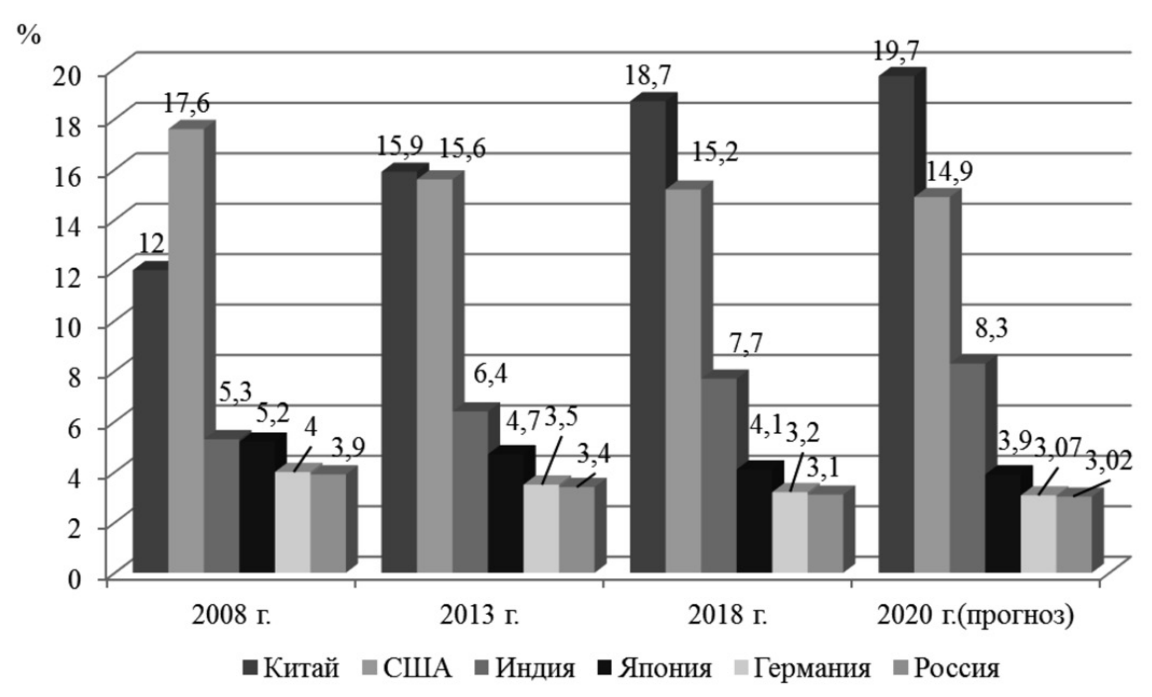

Рис. 1. Динамика роста ВВП

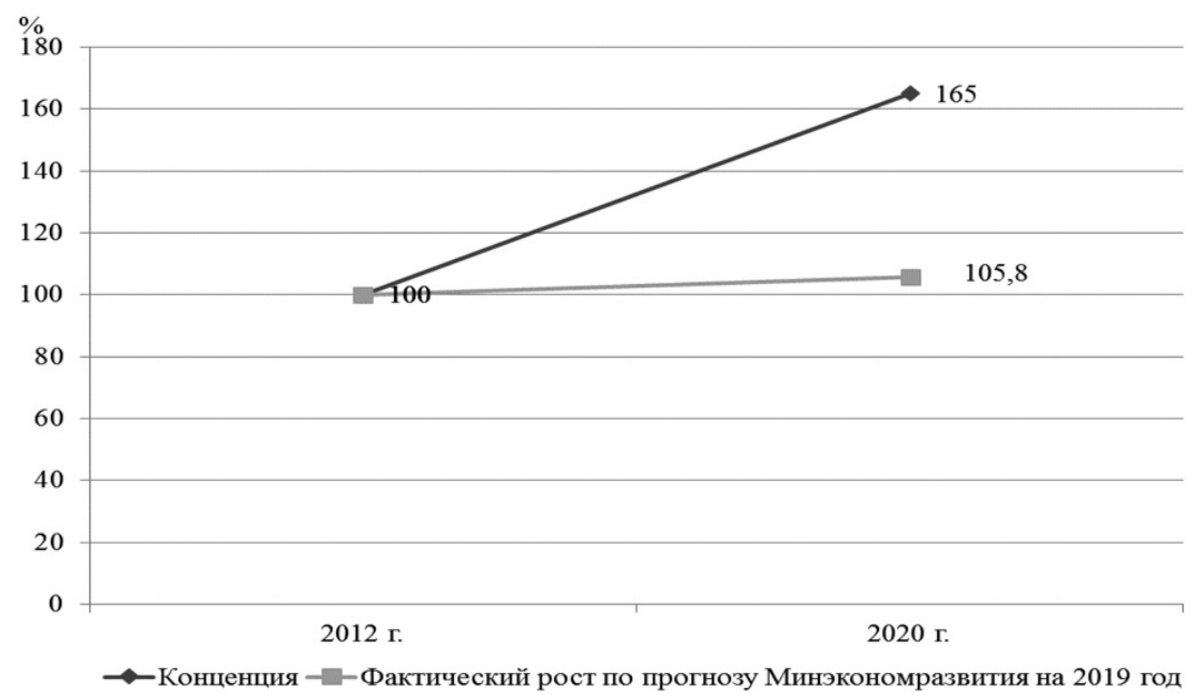

Рис. 2. План и факт по росту ВВП

Одной из целей Концепции являлся рост реальных доходов населения, который должен составить за 2020 год 64-72\% по отношению к 2012 году, однако если доходы населения с 2007 по 2013 годы росли в пределах $22 \%$, то с 2014 года их рост замедлился и сменился около нулевым, к концу 2019 года доходы сократились на $5 \%$ (рис. 3 ) [1].

По расчетам РБК за третий квартал 2019 года заложенные в Концепции параметры роста доходов (164-172\%), составили $95 \%$ (рис. 4).

Документом на 2020 год предусмотрено сокращение уровня абсолютной бедности на $6,4 \%$ по сравнению с 2007 годом $(13,4 \%)$, что должно способствовать росту среднего класса более чем на половину, на сегодня средний класс составляет около $38 \%$ россиян, однако в полной мере соответствуют всем критериям этой категории всего лишь 10,3 млн чел. или $7 \%$ населения страны.

Изменения уровня бедности носят ларифмический характер, так с 2008 года по 2012 он опустился до 10,7\%, начиная с 2016 года вырос и составил 13,3\%, снижение в 2017 и 2018 годах сменилось вновь ростом, по данным Росстата по итогам второго квартала 2019 года зафиксирован рост до $12,7 \%$ (рис. 5), и все же за чертой бедности находится 18,6 млн чел. 


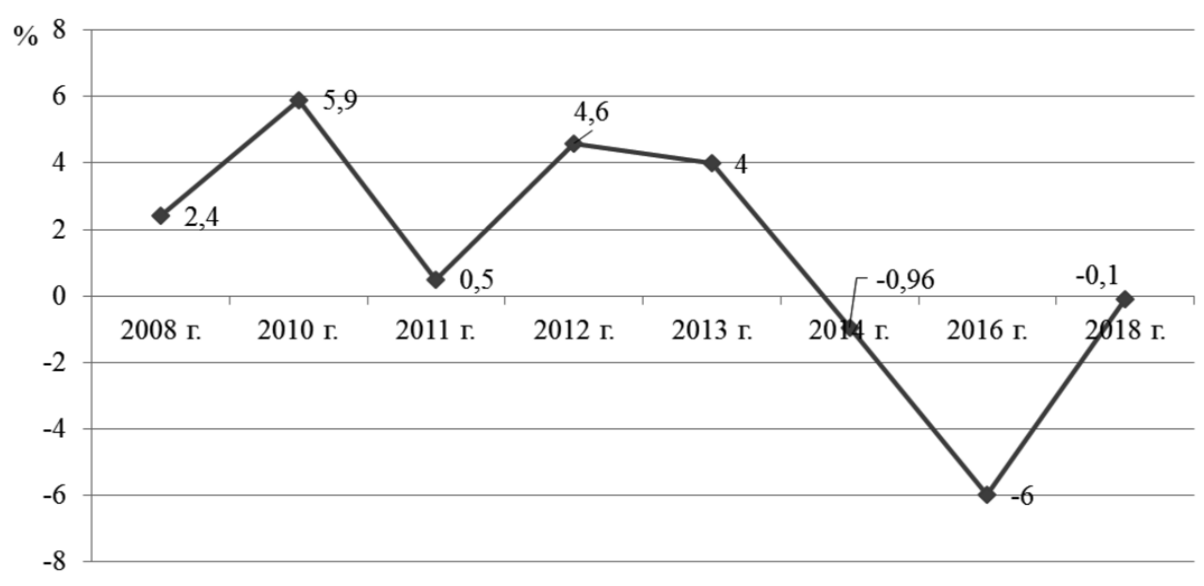

Рис. 3. Динамика роста (снижения) реальных доходов населения

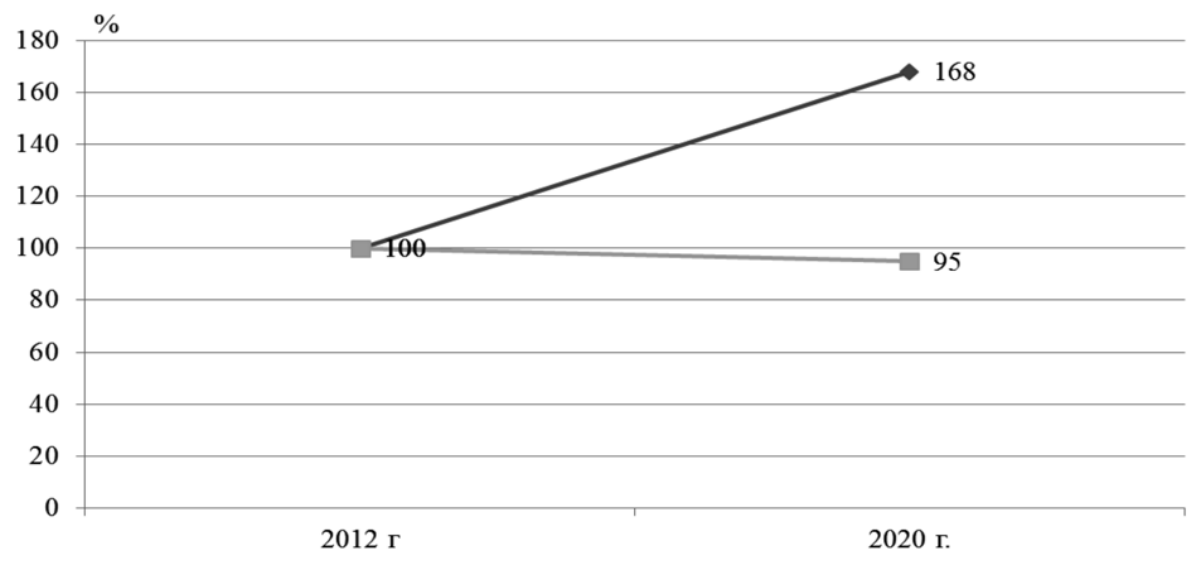

Концепция - -Фактический рост по прогнозу Минэкономразвития на 2019 год

Рис. 4. План и факт по росту реальных денежных доходов населения

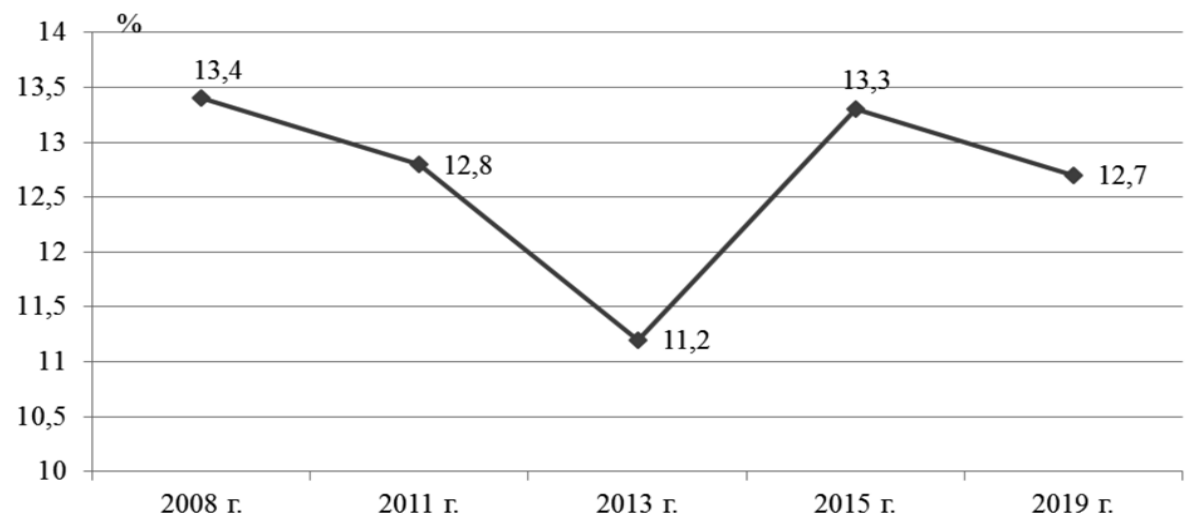

Рис. 5. Динамика населения с доходами ниже прожиточного минимума

Цель, обозначенная в концепции, сохраняется, ее пролонгировали до 2024 года, согласно майскому указу Президента к этому времени уровень бедности должен снизиться в два раза, и это задача самая сложная из всех обозначенных в нем [1].

Одним из главных направлений деятельности государственных органов в центре и на местах является государ- 
ственная жилищная политика, реформа в жилищной сфере находится среди важнейших государственных задач требующих первоочередного решения [2].

Средний уровень обеспеченности жильем к 2020 году должен был составить 28-35 м² на человека, что составляет около $100 \mathrm{M}^{2}$ на среднестатистическую семью, по данным Росстата, в 2018 году в среднем на одного человека приходилось 25,8 м² жилья (рис. 6).

Большое внимание в Концепции уделяется поддержке образования и здравоохранения, так предусмотрено перераспределение бюджета с увеличением рас- ходов в образование и здравоохранение с $8,7 \%$ от ВВП в 2007 году, до $11-17 \%$ в 2020 году, доля расходов на здравоохранение должна увеличиться с $3,6 \%$ ВПП до 5-5,5\%, на образование с 4 до 5-6\% ВВП (рис. 7) [1].

По данным Счетной палаты расходы в образование в ближайшие три года планируются в среднем на уровне 3,7\% ВВП, на здравоохранение $2,9 \%$ ВВП.

Для сравнения на рис. 8 приведены данные финансирования указанных отраслей по странам «Большой семерки» за 2018 год.

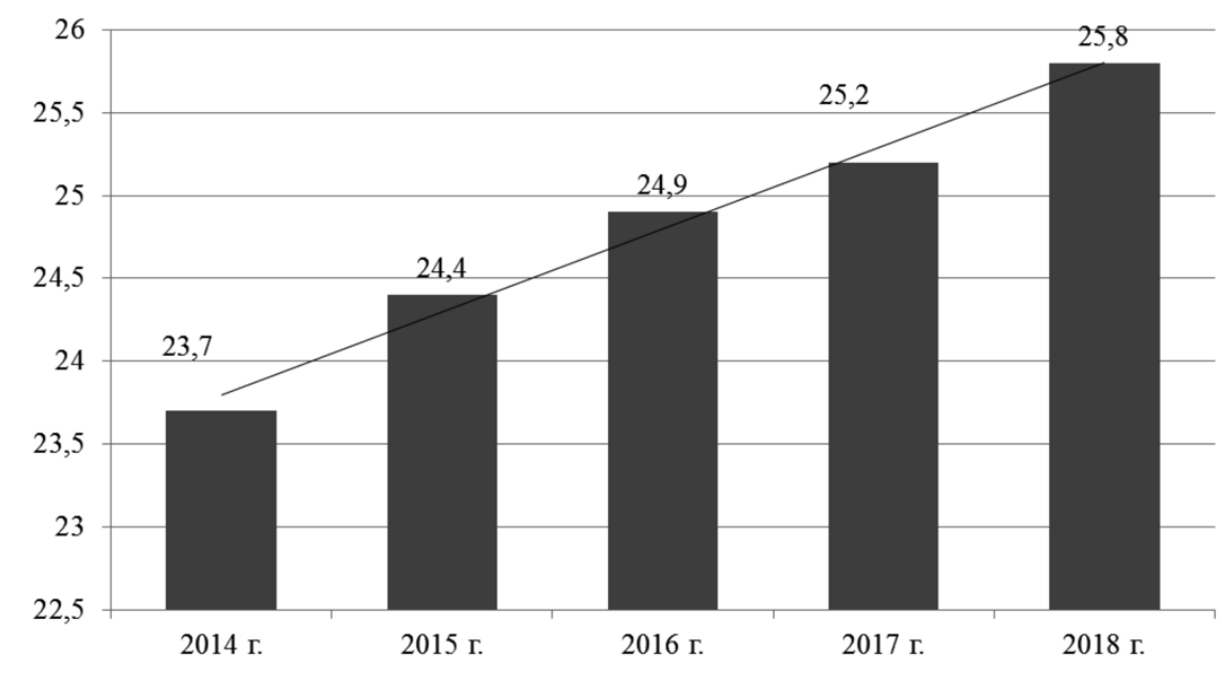

Рис. б. Динамика обеспеченности жильми помещеениями, приходящчимися в среднем на одного человека

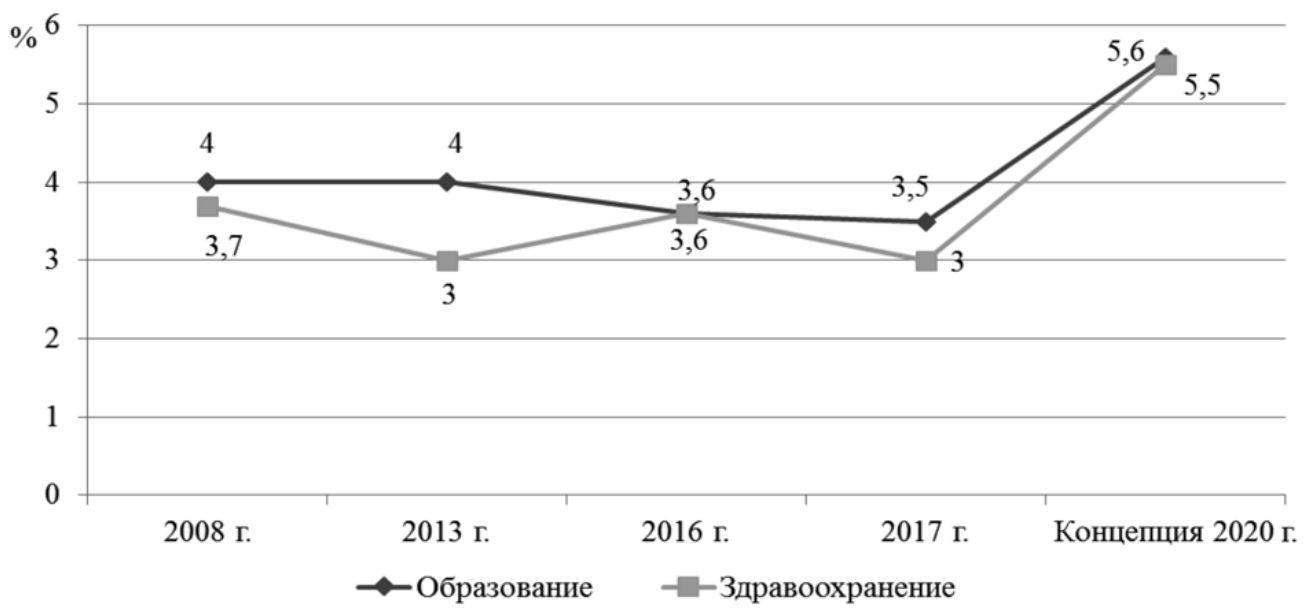

Рис. 7. Расходы государственного бюджета и внебюджетных фондов на образование и здравоохранение 


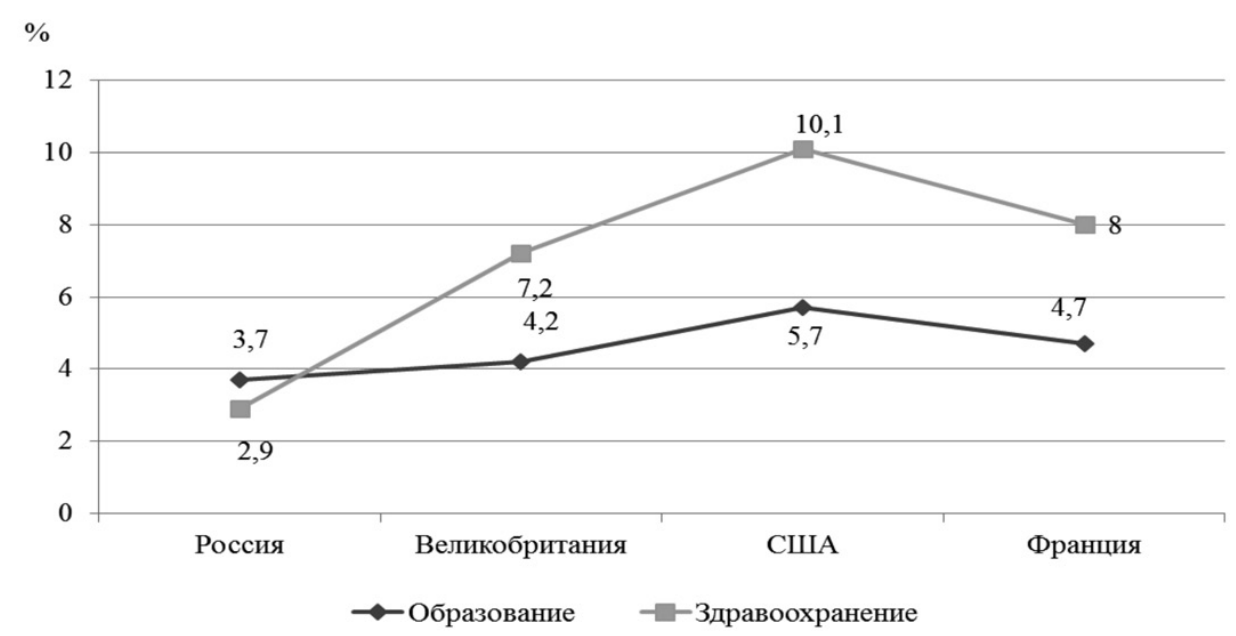

Рис. 8. Финансирование здравоохранения и образования в странах «Большой семерки»

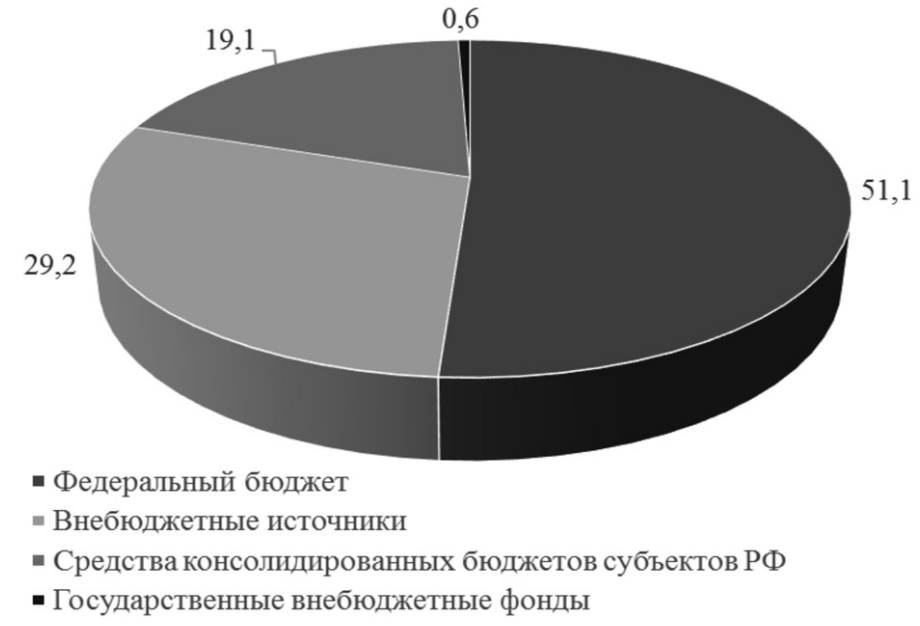

Рис. 9. Структура источников финансирования Национальных Проектов

В рамках реализации государственной антикризисной стратегии одними из применяемых в российской экономике инструментов являются Национальные Проекты. В 2018 году Указом № 204 «О национальных целях и стратегических задачах развития Российской Федерации на период до 2024 года» утвержден ряд Национальных Проектов, сформированных по 12 стратегическим направлениям социально-экономического развития РФ и «Комплексный план модернизации и расширения магистральной инфраструктуры», со сроком реализации до конца 2024 года.

Проекты реализуются в целях осуществления прорывного научно-тех- нологического и социально-экономического развития Российской Федерации, увеличения численности населения страны, повышения уровня жизни граждан, создания комфортных условий для их проживания, а также условий и возможностей для самореализации и раскрытия таланта каждого человека [8].

Предполагается, что все проекты будут на 51,1\% профинансированы из федерального бюджета, на 29,2\% из внебюджетных источников, средства консолидированных бюджетов субъектов РФ составят $19,1 \%$, и $0,6 \%$ средств поступит из государственных внебюджетных фондов (рис. 9) [4]. 


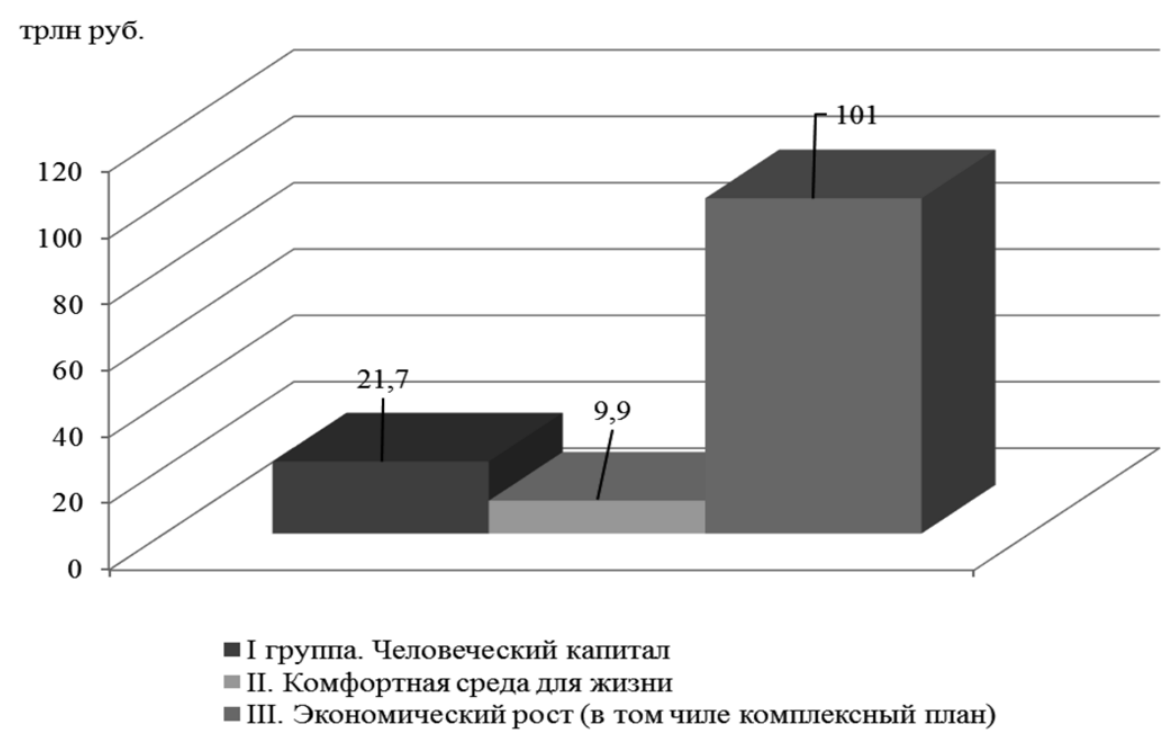

Рис. 10. Группь Нацииональных Проектов и их финансовое обеспечение

Проекты сформированы в три большие группы, каждая из которых включает от трех до пяти направлений. Наибольшая доля средств 52,1\% от общего объема финансирования направляется в первую группу, предусматривающую развитие и поддержку человеческого капитала, 23,6\% финансирования вкладываются в создание комфортной среды проживания, 15,1\% - экономический рост и 9,2\% средств обеспечивают реализацию комплексного плана (рис. 10).

Особенностью финансирования проектов является перенесение большего объема средств на более поздние периоды, только по трем проектам «Здравоохранение», «Демография» и «Цифровая экономика» более $1 / 3$ предполагаемого объема финансирования приходится на первые два года их реализации 20192020 гг. и конец 2018 г. [4]

По ряду проектов из третьей группы, таким как «Наука», «Международная кооперация и экспорт», «Малое и среднее предпринимательство», а также по нацпроекту «Экология» более $40 \%$ финансирования предполагается осуществить в последние два года их реализации 2023-2024 гг.

За первый год реализации удалось достичь не всех запланированных целей, и все же большая часть задач была выполнена, так, из 38 обозначенных на 2019 год 26 решены, но средства, выделенные на реализацию проектов, тратятся медленнее, чем запланировано. Следует отметить, что информация о расходовании средств на нацпроекты достаточно закрыта, хотя публичный контроль, на что потрачены бюджетные средства, очень важен.

По предварительным данным Министерства финансов расходы федерального бюджета на реализацию проектов в 2019 году составили 91,4\% от запланированного на год объема, из 1,75 трлн руб. освоение составило 91 \% (1,6 трлн руб.), самый низкий показатель у нацпроектов «Экология» - 66,3\%, «Цифровая экономика» - 73,3\% и «Производительность труда и поддержка занятости» $-87,1 \%$.

Однако, при реализации Национальных проектов прежде всего важен результат, а не сколько потрачено средств, так как их исполнение отражает государственные приоритеты, следует учитывать специфику разных сфер, так как не все проекты требуют равномерного финансирования, только часть требует крупных вложений уже на начальной стадии.

В Правительстве рассматривается вопрос отказа от оценки промежуточных результатов национальных проектов, все задачи на каждый год реализации исчезнут и останутся только итоговые на 2024 год [10], 2019-й год можно смело назвать годом национальных проектов, 
именно в этом году началась активная работа, направленная на решение прорывных задач развития России, а наличие негативных результатов указывает на необходимость более четкой отстройки «проектных вертикалей» и более жесткой увязки целей и показателей федеральных проектов с целями «майского указа» Президента.

Следует отметить, что национальные проекты, основаны на оптимистическом предположении ежегодного роста ВВП, а между тем, в этом сценарии мировой экономический рост упадет до 3,2 процента к 2024 году и ниже 3 \% процентов после этого, гарантируя, что экономическая мощь России возрастет по сравнению с остальным миром.

Одним из препятствий для успешной реализации национальных проектов являются западные санкции, но они, повлияли на замедление экономики лишь отчасти, ежегодно из-за санкций терялось 0,5\% ВВП, а с точки зрения потенциального роста - 0,3\%, однако следует отметить, что это не тот масштаб проблемы, которая могла бы объяснить расхождение между желаемыми 6\% и фактическими 1-2\% роста [1], потенциально гораздо более разрушительным для долгосрочных экономических перспектив России является кризис доверия между предпринимателями и инвесторами.

Внутренние инвестиции частного сектора крайне низки, в 2018 году инвестиции в основной капитал составили , а все более репрессивный контроль, стагнация в заработной плате и сырой экономический рост подорвали доверие бизнес-класса, который не хочет вкладывать средства и развивать свой бизнес, то есть те, кто ведет бизнес с государством, используя личные связи, также не желают инвестировать, предпочитая вынимать свою прибыль из своих компаний в виде наличных: в настоящее время Россия имеет самые высокие дивидендные доходы в мире - в два раза выше уровня эталон MSCI EM средний.

В течение почти трех десятилетий Россия имела чистый приток капитала всего за два года, в 2006 и 2007 годах. в разгар бума, когда российские предприниматели вернули в страну 131 млрд долларов, а когда разразился кризис 2008 года, 133 миллиарда долларов снова сбежали, и с тех пор Россия каждый год переживает отток капитала.

Прямые иностранные инвестиции России (ПИИ), исключая реинвестирование, в 2018 году сократились до 1,9 млрд. долларов США, а если вычесть прибыль, реинвестированную иностранными компаниями, уже работающими в России, то фактически Россия не получает никаких внешних инвестиций, за исключением нескольких мега сделок, заключенных с Китаем, даже с учетом реинвестирования ПИИ в России в 2015-2018 годах составляли в среднем 1,5 процента ВВП, по данным Института международных финансовсамый низкий за последние 20 лет.

Для стабилизации экономической ситуации Правительством был разработан план антикризисного развития страны на 2018-2019 год, в рамках которого представлены шаги, которые предполагается предпринять для обеспечения качественного развития экономики и социальной стабильности в период сложной внешнеполитической обстановки, однако документ, несмотря на важную задачу, мало отличается от типового плана законопроектной деятельности, который утверждает Правительство на текущий период времени [6].

И все же замедление темпа роста российской экономики обусловлено сегодня больше структурными ограничениями, такими как усложнение демографической ситуации, а также спадом инвестиционной активности, и в этой непростой ситуации объективно возрастает роль государства в экономической жизни страны. В связи с чем Правительство Российской Федерации намерено значительно активизировать использование всех имеющиеся инструментов экономической и социальной политики в целях недопущения необратимых разрушительных процессов в экономике, подрывающих долгосрочные перспективы развития страны, обеспечивая при этом и решение стратегических задач [3].

\section{Заключение}

Для повышения эффективности антикризисного управления важно определить и начать применять на практике, даже в фазе рецессии, меры, которые могли бы позволить перейти от защи- 
ты «наиболее уязвимых» экономических агентов к защите их интересов, а также поддержки «новых двигателей роста», которые могут значительно ускорить посткризисное экономическое возрождение.

Прежде всего было бы разумно провести процедуры генерации и внедрения антикризисной политики более обоснованно и прозрачно, при этом все принятые законодательные акты по антикризисным мерам должны пройти обязательную проверку на соответствие требованиям законодательства.

Немаловажным вопросом является оценка антикризисного управления. Оценивая антикризисные меры, следует акцентировать внимание не на обсуждении их пригодности, а на том, что они могут быть приняты, на оценке используемых инструментов регулирования, а также, соответствующих правил и механизмов, обеспечивающих их выполнение, но существует проблема - обилие квазигосударственных мер на пути антикризисной политики правительства, они слишком непрозрачны, чтобы их можно было легко оценить.
Несмотря на то, что та новая экономическая модель призвана повысить темпы экономического роста в России выше среднего мирового уровня и будет опираться на впечатляющие реформы в банковском и налоговом секторах, успех этих усилий далеко не гарантирован.

В этой связи обязанность властей состоит в том, чтобы попытаться разрешить кризис, используя все возможное, начиная с уверенности в себе и заканчивая способностью поглотить гнев или страх общественности, не нанося ущерба доходу или репутации, так как имидж-это важная функциональная и статусная ценность, кроме этого, он является индикатором того, что уровень доверия и показатель эффективности управленческой деятельности, осуществляемой в соответствии с реформами, фиксирующими степень соответствия действий требованиям законодательства, требованиям и ожиданиям конкретных социальных групп и национальной экономики, а компетентность антикризисного управления во многом определяет отношение общества к нему.

\section{Библиографический список}

1. Концепция развития России до 2020 года оказалась невыполнимой. Почему разошлись траектории национальных целей 2008 года и фактического развития страны [Электронный ресурс]. URL: https://www.rbc.ru/economics/02/11/2019/5db946fb9a794742bc0d5b68 (дата обращения: 18.03.2020).

2. Проблемы обеспечения населения жильем. [Электронный ресурc]. URL: https://magref.ru/ problemyi-obespecheniya-naseleniya-zhilem/ (дата обращения: 18.03.2020).

3. Стратегия бюджета развития, бизнеса и тактические инновационные стратегии бюджета РФ. [Электронный ресурc]. URL: http://www.rusnauka.com/44_NIOBG_2016/Economics/9_218464. doc.htm (дата обращения: 13.04.2020).

4. Финансирование национальных проектов [Электронный pecypc]. URL: https://icss.ru/ ekonomicheskaya-politika/strategicheskoe-planirovanie/kopiya-vneshnyaya-torgovlya-v-2018-godu-inatsionalnye-proekty (дата обращения: 10.03.2020).

5. [Электронный ресурс]. URL: http://www.consultant.ru/cons/cgi/online.cgi?req=doc\&base=LAW $\& \mathrm{n}=308069 \& \mathrm{fld}=134 \& \mathrm{dst}=100069,0 \& \mathrm{rnd}=0.6259962548970328 \# 0052928151839619186$ (дата обращения: 13.03.2020).

6. [Электронный ресурс]. URL: http://www.garant.ru/article/608356/\#ixzz6FX3Q2DKs (дата обращения: 10.03.2020).

7. [Электронный ресурс]. URL: https://rg.ru/2018/05/08/president-ukaz204-site-dok.html (дата обращения: 7.04.2020).

8. [Электронный ресурс]. URL: https:/viafuture.ru/privlechenie-investitsij/strategiya-2020 (дата обращения: 11.04.2020).

9. [Электронный ресурс]. URL: https://www.minfin.ru/ru/press-center/?id 4=36929-predvaritelnye dannye_ob_ispolnenii_raskhodov_federalnogo_byudzheta_na_ryealizatsiyu_natsionalnykh_proektov_ na 1 yanvarya 2020 goda (дата обращения: 6.03.2020).

10. [Электронный ресурс]. URL: https://www.rbc.ru/economics/07/03/2020/5e63d3459a7947cc5 cd55594 (дата обращения: 10.04.2020). 